\title{
Making: Laboratory and Active Learning Perspectives
}

\author{
Margherita Di Stasio
}

\begin{abstract}
In a world where technology is an ordinary part of everyday life, it is particularly important for making, coding, and educational robotics to feature in school programs. On one hand, the construction elements that are peculiar to digital fabrication make the pedagogical perspective active; on the other, they can support the development of active teaching practices. Although it appears to be a kind of revolution, something that is absolutely new, on deeper reflection, it is clear that making and coding can play a role in school as part of an important pedagogical tradition.
\end{abstract}

Keywords Active learning $\cdot$ Making $\cdot$ Coding $\cdot$ Educational robotics $\cdot$ Active pedagogical perspective $\cdot$ Laboratory

\section{Introduction}

A fundamental trend in public opinion and in 21 st-century policy-making worldwide has been the call for the digital and technological development of school.

From the Recommendation of the European Parliament and of the Council on key competences for lifelong learning, published in 2006 and revised in 2018, to the Every Student Succeeds Act passed in 2015-2016, technology has an important role to play in lifelong education. Beginning as a separate competence for the purpose of achieving confident use of computers and the opportunities offered by the web, technological competence has gradually become a multidimensional competence, not only oriented to the use of tools. The technological evolution of the world has brought the need for all people, and particularly the young generations, to develop another kind of digital consciousness based on a creative and constructive commitment.

From an educational perspective, it is no longer sufficient to teach the use of computers or technological artifacts for everyday life and work proficiency; it is also

\footnotetext{
M. Di Stasio (ه)

Istituto Nazionale Documentazione Innovazione Ricerca Educativa (Indire), Florence, Italy e-mail: m.distasio@indire.it
} 
necessary to foster engagement with technology through creative and constructive paths, such as coding and making.

From this point of view, making can be seen as an active pedagogical approach.

\section{Making as a Bridge Between Pedagogical Tradition and Technological Innovation}

Since the beginning of the twentieth century, many key authors have stressed the importance of the learning process and the role that experience can play, with a particular focus on experience and learning by doing.

According to Dewey (1938), it is important for students to face a problem emerging from a real situation related to their experience, in order to stimulate thought. It is important for students to handle the elements necessary for solving the problem; it is also important for them to be able to develop solutions that they can test in practice.

In order to acquire persistent and significant knowledge, students need to be involved actively, in a learning process that is linked to their reality and their experiences.

Technology and technological instruments can be included in students' experience and are part of their surroundings. Technology, machines and techniques can also be a functional part of the learning environment. Célestin Freinet gives us an in-depth analysis of this point.

The classroom becomes a learning environment when it evolves through technologies. Every new technology or technique presupposes that it will be introduced into the work cycle of a new instrument that is better suited to meeting the needs of the technical and social environment. According to Freinet (1967), for school to be improved, school equipment needs to be modernized. This does not mean merely buying new materials. It demands a profound change in pedagogical terms in order to construct what Freinet describes as the school of the future, centered on children as community members (Freinet 1957).

In this brief historic excursus, we discover Seymour Papert's constructionism to be the closest precursor to maker pedagogy. Concerning the role of technologies in education, as noted, "Papert advocates technology in schools not as a way to optimize traditional education, but rather as an emancipatory tool that puts the most powerful construction materials in the hands of children-again, another idea that inspired the resurgence of the 'maker' sensibilities" (Blikstein 2013). The deep connection between constructionism and making is also evident in Papert's (1991) words when he suggests that constructionism should be thought of as "learning-by-making." He defines the constructivist view of learning as "building knowledge structures."

This leads us to think of making as a manipulative version of knowledge-building processes and to reflect on the tradition of the collaborative construction of knowledge (Scardamalia and Bereiter 2006; Brown and Campione 1994). 
In the maker approach we can find the main features outlined in this excursus: experience and learning by doing; technologies as a basis for rethinking the learning environment; manipulation and construction of knowledge as a social and shared activity.

\section{Technology, People, Society}

As we can see in the contributions collected in this section, some features of making in the educational context can manifest in a specific way. The technical aspect can be read in terms of the relationship between people and technology, the importance of prototyping for building knowledge, the innovation of teaching practices through technology, method and environment; the confidence that the maker approach can build through technology can finally make way for the specific aspect of digital citizenship.

\subsection{Experiences and Point of View}

Considering Freinet, Malaguzzi and Munari's pedagogical models, in her contribution The Maker Movement: From the Development of a Theoretical Reference Framework to the Experience of DENSA Coop. Soc, Valentina Costa emphasizes the role of techniques as a basis for sharing knowledge construction as a distinctive aspect of the maker movement approach.

The relationship between the technical aspects and the educational impact of the use of the 3D printer is the focus of Di Tore et al. in Learning by Making: 3D Printing Guidelines for Teachers. Specifically, they analyze the impact of 3D printer features, such as resolution, type of materials and timings, in relation to their use in subject teaching.

In Furniture Design Education with 3D Printing Technology, Meltem Eti Proto and Ceren Koc Saglam consider the use of the 3D printer in the construction of a design method based on the experience of a university furniture design course.

In Makerspaces for Innovation in Teaching Practices, Giuseppe Alberghina approaches the theme of rapid prototyping as the basis for the integration between fab labs, makerspaces and school, and for innovating the education system through traditional teaching practices and making.

With a focus on the potential connection between making, coding and other methods, in Service Learning: a Proposal for the Maker Approach, Frazzarin and Leonori present an experience of service learning during which coding activities take place. 
Also, organizational changes are needed for a real innovation in practices: this is the perspective with which Ricciardi et al. view a of teacher training experience for tinkering activities in their contribution Officina degli Errori: An Extended Experiment to Bring Constructionist Approaches to Public Schools in Bologna.

In Fab the Knowledge, Scataglini and Busciantella Ricci focus on the collaborative dimension that making can support through participatory design processes and underline the possibilities that making can open up in terms of project-based and inquiry-driven education.

In Chesscards: Making a Paper Chess Game with Primary School Students, a Cooperative Approach, Agnese Addone and Luigi De Bernardis underline motivation and the engagement of students involved in a learning process based on a collaborative and active approach.

Also, the construction, implementation and setup of a fab lab can be a process that strengthens a community by connecting different realities in the territory.

In Montessori Creativity Space: Making a Space for Creativity, Fattizzo and Vania describe and analyze the process of implementing a makerspace in a school based on Malaguzzi's concept of atelier, as an experience of collaboration by the entire school community.

In Museum Education Between Digital Technologies and Unplugged Processes. Two Case Studies, Carlini describes an experience of museum education in which the setup of a school fab lab is part of a process that involves several institutions in the territory: school, museum, and municipality.

The introduction of a maker approach in the educational context involves a new kind of relationship between people and technology.

On one hand, from a maker perspective it is possible to gain a deeper understanding of technology.

Going in this direction is Anatasia Pyrini's contribution, Teaching Environmental Education Using an Augmented Reality World Map, which discusses the theme of digital citizenship and competence, and looks at how this can be developed at school, with students and with teachers.

In Roboticsness-Gymnasium mentis, Lisimberti and Aprile present an experience in which making and educational robotics are the paths to bring school closer to everyday digital and technological reality, in which students acquire skills to become prosumers who can take part in and navigate a complex world.

On the other hand, technology tends to adapt to the needs of school, placing itself in a human-centered perspective. This kind of process is described in A New Graphic User Interface Design for 3D Modeling Software for Children where Giraldi et al. put forward a concept for a graphic user interface designed for preschool children.

\section{Conclusions}

The making approach can bring a new way of achieving several didactic aims in school. On one hand, maker pedagogy can update to the digital era what we can consider the magna pars of an active approach to contemporary education. On the 
other, the awareness of technology that is gained from making can build-in addition to technological competence - the technological literacy that is needed for full digital citizenship.

In this evolution of the relationship between school, technology and lifelong learning, making and coding take their place in education, not only as education technology and practical activities, but also as basic ideas for defining "clusters of innovative pedagogical approaches" (Paniagua and Istance 2018).

\section{References}

Blikstein, P.: Digital fabrication and 'making' in education: the democratization of invention. FabLabs: Mach. Makers Inventors 4(1), 1-21 (2013)

Brown, A.L., Campione, J.C.: Guided discovery in a community of learners. In: McGilly, K. (ed.) Classroom Lessons: Integrating Cognitive Theory and Classroom Practice. MIT Press/Bradford Books, Cambridge, MA (1994)

Dewey, J.: Experience and Education. Macmillan, New York (1938)

Freinet, C.: L'école moderne française: guide pratique pour l'organisation matérielle, technique et pédagogique de l'Ecole Populaire. Editions Rossignol, Vienne (1957)

Freinet, C.: Les techniques Freinet de l'école moderne. Armand Colin, Paris (1967)

Paniagua, A., Istance, D.: Teachers as Designers of Learning Environments: The Importance of Innovative Pedagogies, Educational Research and Innovation, OECD Publishing. Paris (2018). https://doi.org/10.1787/9789264085374-en

Papert, S., Harel, I.: Situating constructionism. Constructionism 36(2), 1-11 (1991)

Scardamalia, M. \& Bereiter, C.: 'Knowledge Building: Theory, Pedagogy, and Technology', The Cambridge Handbook of the Learning Sciences, 97-115, (2006).

Open Access This chapter is licensed under the terms of the Creative Commons Attribution 4.0 International License (http://creativecommons.org/licenses/by/4.0/), which permits use, sharing, adaptation, distribution and reproduction in any medium or format, as long as you give appropriate credit to the original author(s) and the source, provide a link to the Creative Commons license and indicate if changes were made.

The images or other third party material in this chapter are included in the chapter's Creative Commons license, unless indicated otherwise in a credit line to the material. If material is not included in the chapter's Creative Commons license and your intended use is not permitted by statutory regulation or exceeds the permitted use, you will need to obtain permission directly from the copyright holder.

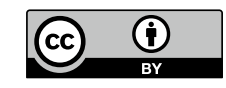

